\title{
Identifikasi Bentuk dan Dampak Kekerasan Pada Anak Usia Dini di Kota Yogyakarta
}

\author{
Alif Muarifah ${ }^{1}$, Dewi Eko Wati ${ }^{2}$, Intan Puspitasari ${ }^{\varpi_{3}}$ \\ Pendidikan Guru Pendidikan Anak Usia Dini, Universitas Ahmad Dahlan \\ DOI: $10.31004 /$ obsesi.v4i2.451
}

\begin{abstract}
Abstrak
Anak usia dini merupakan salah satu yang rentan mengalami kekerasan dari orangtua atau pengasuhnya. Tujuan penelitian ini untuk mengidentifikasi bentuk-bentuk kekerasan orang tua terhadap anak, faktor penyebab kekerasan, dan dampak fisik maupun psikologis yang dialami anak. Hasil identifikasi selanjutnya digunakan sebagai dasar penelitian lanjutan dan penanganan psikologis bagi orang tua yang melakukan kekerasan terhadap anak. Data penelitian dikumpulkan dengan menggunakan angket dan dianalisis dengan teknik deskriptif kualitatif. Partisipan dalam penelitian ini berjumlah 320 orang tua yang memiliki anak usia 4-6 tahun yang bersekolah di Gondomanan, Umbulharjo, Gedongtengen, dan Ngampilan dengan menggunakan teknik cluster sampling. Hasil penelitian menunjukkan bahwa dari 14 pilihan bentuk kekerasan, yang paling banyak dilakukan orangtua terhadap anak adalah mencubit dan memelototi. Kecamatan Gedongtengen memberikan respon paling banyak hampir di setiap bentuk kekerasan. Alasan terbanyak orangtua melakukan kekerasan adalah untuk mendisiplinkan anak. Hal ini menyebabkan anak menangis ketika orangtua melakukan kekerasan terhadap mereka.
\end{abstract}

Kata Kunci: bentuk-bentuk kekerasan; dampak kekerasan; faktor kekerasan; anak usia dini.

\begin{abstract}
Early childhood is one who is vulnerable to violence from parents or caregivers. The purpose of this study was to identify types of parental violence against children, the causes of violence, and the physical and psychological impacts experienced by children. The identification results are then used as a basis for further research and psychological treatment for parents who commit violence against children. Research data were collected using a questionnaire and analyzed with qualitative descriptive techniques. Participants in this study were 320 parents who have children aged 4-6 years who attend school in Gondomanan, Umbulharjo, Gedongtengen, and Ngampilan by using cluster sampling techniques. The results showed that of the 14 choices of violence, the most parents carried out against children were pinching and glaring. Gedongtengen District gives the most responses in almost every types of violence. The most reason parents do violence is to discipline their children. This causes children to cry when parents abuse them.
\end{abstract}

Keywords: types of violence; impact of violence; violence factor; early childhood.

Copyright (c) 2020 Alif Muarifah, Dewi Eko Wati, Intan Puspitasari

Corresponding author :

Email Address : intan.puspitasari@pgpaud.uad.ac.id ( Jl. Ki Ageng Pemanahan No. 19 Sorosuta

Umbulharjo Yogyakarta, Intan Puspitasari )

Received 29 January 2020, Accepted 5 February 2020, Published 8 February 2020 


\section{PENDAHULUAN}

Usia dini (0-6 tahun) sering dinamakan masa golden age atau usia keemasan dimana struktur otak mirip dengan spon dengan daya serap tinggi terhadap informasi. Pada masa ini, anak sedang menjalani suatu proses perkembangan dengan pesat dan mampu menyerap berbagai informasi yang menjadi dasar bagi kehidupan selanjutnya (Sugiyono, 2008). Anak usia dini memiliki kebutuhan yang harus dipenuhi untuk menunjang perkembangan yang optimal. Kebutuhan utama pada usia dini ini diantaranya adalah, kebutuhan jasmaniahbiologis, rasa aman terjamin (security and savety), rasa kasih sayang dan dihargai (love and esteem), serta aktualisasi diri (self actualization).

Kehadiran seorang anak di sebuah keluarga tidak selamanya mendapatkan perlindungan yang layak, khususnya dari orangtua. Beberapa anak yang kurang beruntung mendapatkan perlakuan keras, penelantaran bahkan penyiksaan yang dilakukan oleh orangtuanya sendiri. Kondisi ini menyebabkan kebutuhan utama seorang anak tidak terpenuhi. Lebih lanjut jika dilihat dari perspektif perkembangan sosial emosi, bagaimana sebuah keluarga memberikan perlakuan pada anak akan menentukan sukses atau tidaknya anak tersebut berinteraksi dengan lingkungannya kelak. Hal ini berkaitan dengan sikap secure atau insecure khususnya ketika anak berada di lingkungan baru tanpa pendampingan orangtua (Puspitasari \& Wati, 2018). Anak yang mendapatkan cukup kasih sayang dari orangtuanya cenderung lebih berani ketika masuk dalam lingkungan baru dibandingkan anak yang tidak mendapatkan kasih sayang serupa.

Hasil survey KPAI tahun 2012 di 9 provinsi menunjukkan bahwa 91\% anak menjadi korban kekerasan di lingkungan keluarga, 87.6\% di lingkungan sekolah dan $17.9 \%$ di lingkungan masyarakat. Anak yang mendapat kekerasan dari orangtua akan mengalami dampak internal maupun eksternal. Secara internal, anak yang mendapatkan kekerasan dan kurang kasih sayang dari orangtuanya menjadi salah satu faktor kecemasan (Tamisa, 2016). Penekanan yang dialami oleh anak dapat memunculkan rasa takut yang membatasi kebebasan dalam bereksplorasi. Sedangkan secara eksternal, anak akan melihat kekerasan yang dilakukan orangtuanya sehingga menyimpan peristiwa tersebut dalam ingatan dan mungkin menirukannya di kemudian hari. Sebanyak $78.3 \%$ anak melakukan kekerasan karena memiliki pengalaman sebagai korban kekerasan sebelumnya (Setyawan, 2015). Data tersebut dapat dikaji berdasarkan pandangan Bandura mengenai konsep modelling. Modelling atau meniru merupakan salah satu cara belajar pada anak usia dini dengan mengobservasi, mengingat, mereproduksi, kemudian mendapat motivasi dari orang di sekitar (Connolly, 2017).

Kekerasan terhadap anak menjadikan anak tidak berdaya sehingga memiliki dampak negatif terhadap perkembangan psikologisnya. Beberapa bentuk kekerasan yang biasanya dilakukan pada anak seperti kekerasan fisik dan kekerasan psikologis. Kekerasan fisik dalam hal ini adalah segala bentuk kontak fisik yang dilakukan untuk melukai atau menyakiti orang lain. Sedangkan kekerasan emosional apabila orangtua mengabaikan anak ketika meminta perhatian (Putri \& Santoso, 2012). Kekerasan psikologis dapat berupa ejekan, degradasi, perusakan harta benda, kritik yang berlebihan, tuntutan yang tidak pantas, pemutusan komunikasi dan pelabelan atau penghinaan (Nindya \& Margaretha, 2012). Dengan demikian dapat dikatakan bahwa kekerasan pada anak adalah perlakuan terhadap anak yang dapat menyakiti fisik maupun emosional anak sehingga menimbulkan kejiwaannya terganggu atau tidak stabil.

Pelaku kekerasan bisa saja berasal dari orang-orang yang seharusnya menjadi pelindung bagi anak itu sendiri, misalnya orang tua, kerabat dekat, tetangga, hingga guru. Beberapa alasan orangtua melakukan kekerasan pada anak antara lain adanya riwayat orangtua mengalami kekerasan saat kecil, imaturasi emosi, kepercayaan diri rendah, kurangnya dukungan sosial, memiliki banyak anak hingga ketidaktahuan mengenai pengasuhan (Widiastuti \& Sekartini, 2005). Padahal orangtua adalah sosok yang paling 
DOI: 10.31004/obsesi.v4i2.451

bertanggung jawab dalam mengupayakan kesejahteraan, perlindungan, peningkatan kelangsungan hidup, dan mengoptimalkan tumbuh kembang anak.

Kekerasan orangtua terhadap anak usia dini di kota Yogyakarta sendiri belum teridentifikasi secara detail. Selain menjadi topik yang masih tergolong tabu untuk dibicarakan, bentuk-bentuk perlakuan orangtua terhadap anak yang dapat digolongkan ke dalam kekerasan belum jelas batasannya. Namun, beberapa perlakuan keras yang teramati dari lingkungan sekitar seperti orangtua berteriak pada anak, memberi label anak, membandingkan dengan anak tetangga, menyeret anak ketika orangtua terburu-buru, dsb. Perlakuan yang teramati tersebut disusun dalam sebuah survey untuk mengetahui bentukbentuk kekerasan, faktor, serta dampak yang dialami pada anak. Hasil dari penelitian ini menjadi dasar bagi peneliti untuk melihat kondisi pengasuhan di lingkungan Yogyakarta serta menjadi dasar untuk memberikan intervensi yang sesuai dalam mencegah adanya tindak kekerasan pada anak usia dini.

\section{METODOLOGI}

Peneliti menggunakan angket untuk melakukan pengambilan data lalu menganalisanya secara statistik dan menguraikannya secara deskriptif. Analisa statistik dilakukan dengan menghitung berapa banyak aitem pertanyaan tersebut dijawab oleh subjek. Alur penelitian digambarkan dalam gambar 1 berikut

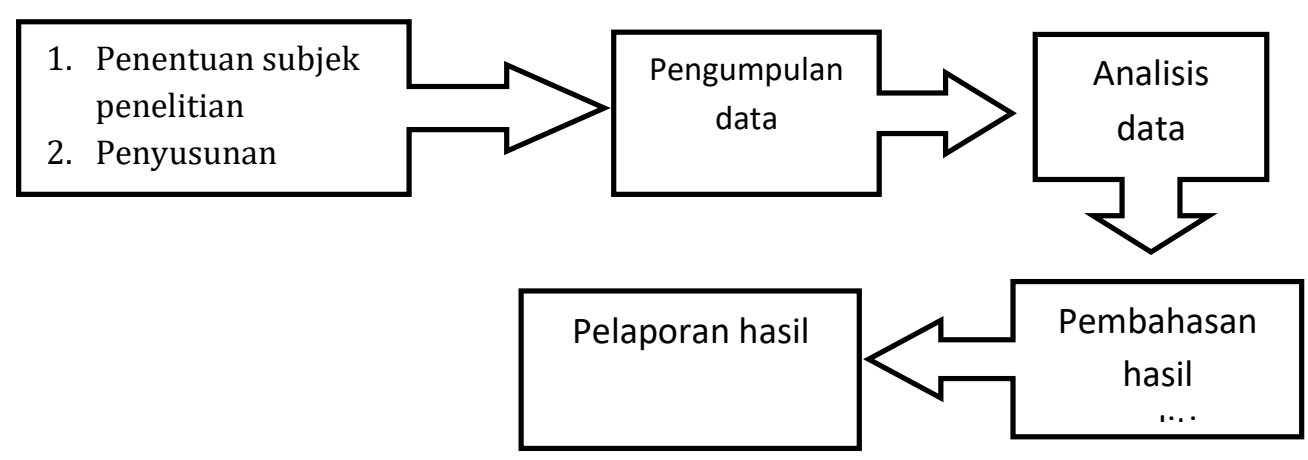

\section{Gambar 1. Alur Penelitian}

Populasi penelitian ini sejumlah 3200 orang yang tersebar di beberapa kecamatan di kota Yogyakarta. Pengambilan subjek penelitian menggunakan kriteria $10 \%$ dari total populasi. Sehingga subjek penelitian ini berjumlah 320 orang. Peneliti menggunakan teknik cluster sampling untuk menentukan kecamatan mana yang akan diambil dengan mempertimbangkan banyaknya jumlah Taman Kanak-Kanak dan murid yang ada di wilayah tersebut. Peneliti mengambil kecamatan Gondomanan, Umbuljarjo, Ngampilan, dan Gedongtengen dengan masing-masing kecamatan.

Angket terdiri dari 12 aitem yang dikelompokkan dalam 4 fokus. Fokus pertama adalah bentuk-bentuk kekerasan yang pernah dilakukan orangtua, di bagian ini orangtua diminta menyebutkan kekerasan apa saja yang pernah dilakukan pada anak; fokus kedua adalah dampak psikologis setelah kekerasan dilakukan, meliputi kondisi psikologis anak dan orangtua setelah melakukan kekerasan; fokus ketiga adalah penyebab orangtua melakukan kekerasan yaitu faktor-faktor yang memicu kekerasan terjadi; serta fokus ke empat adalah pengetahuan orangtua mengenai kekerasan yaitu pandangan orangtua mengenai tindak kekerasan tehadap anak. Aitem-aitem merupakan pertanyaan tertutup dengan pilihan jawaban yang telah disediakan oleh peneliti. Respon yang terkumpul kemudian dipetakan menurut fokus dan dikaji dengan menggunakan literatur yang relevan. 


\section{HASIL DAN PEMBAHASAN}

Salah satu aitem dalam kuisioner menanyakan tentang pandangan orangtua terhadap tindak kekerasan terhadap anak. Dari 320 jawaban yang diterima peneliti mendapati hanya 2 responden $(2 \%)$ yang berpendapat bahwa kekerasan terhadap anak boleh dilakukan sedangkan 210 responden (63\%) berpendapat bahwa kekerasan terhadap anak tidak boleh dilakukan dan sebanyak 118 responden (35\%) berpendapat bahwa dengan alasan tertentu kekerasan terhadap anak boleh dilakukan. Pada penelitian ini, mayoritas responden secara kognitif menunjukkan kesadaran bahwa kekerasan terhadap anak seharusnya tidak dilakukan. Hal ini dibuktikan dengan mayoritas responden setuju bahwa kekerasan terhadap anak tidak boleh dilakukan dengan alasan apapun. Namun menurut data penelitian ini responden juga melaporkan pernah melakukan kekerasan terhadap anak dalam berbagai bentuk. Bentuk-bentuk tindakan orangtua terhadap anak dapat dilihat dalam grafik 1.

Fitriana, Pratiwi dan Sutanto (2015) menemukan bahwa beberapa faktor yang menyebabkan orangtua melakukan kekerasan pada anak antara lain tingkat pengetahuan, sikap, pengalaman dan pengaruh lingkungan. Begitu pula yang diungkapkan oleh penelitian lain bahwa faktor yang mempengaruhi kekerasan pada anak antara lain penyesuaian emosi orangtua, sikap orangtua terhadap pengasuhan dan perilaku orangtua saat mengasuh anak (Lundahl et al., 2006). Dalam hal ini orangtua dilihat sebagai faktor utama ketika terjadi kekerasan terhadap anak.

Seringkali orangtua melakukan kekerasan pada anak ketika berada di bawah kondisi tertekan. Individu memiliki kemampuan yang berbeda-beda dalam menyikapi tekanan tersebut. Beberapa orang sangat baik dalam memberikan respon positif terhadap situasi negatif, namun tidak sedikit orang yang kurang baik dalam memberikan respon positif terhadap situasi serupa. Kemampuan agar tetap tenang ketika berada di bawah tekanan ini disebut dengan regulasi emosi. Data yang didapat peneliti mengungkapkan bahwa orangtua mengetahui bahwa kekerasan pada anak sebaiknya tidak dilakukan. Namun pada kenyataannya kekerasan fisik menjadi bentuk kekerasan terbanyak yang dilakukan dan merasa menyesal setelah melakukan kekerasan tersebut. Hal ini menunjukkan adanya ketidaksesuaian antara kognisi (berupa informasi), psikomotor (perilaku kekerasan) dan afeksi (penyesalan).

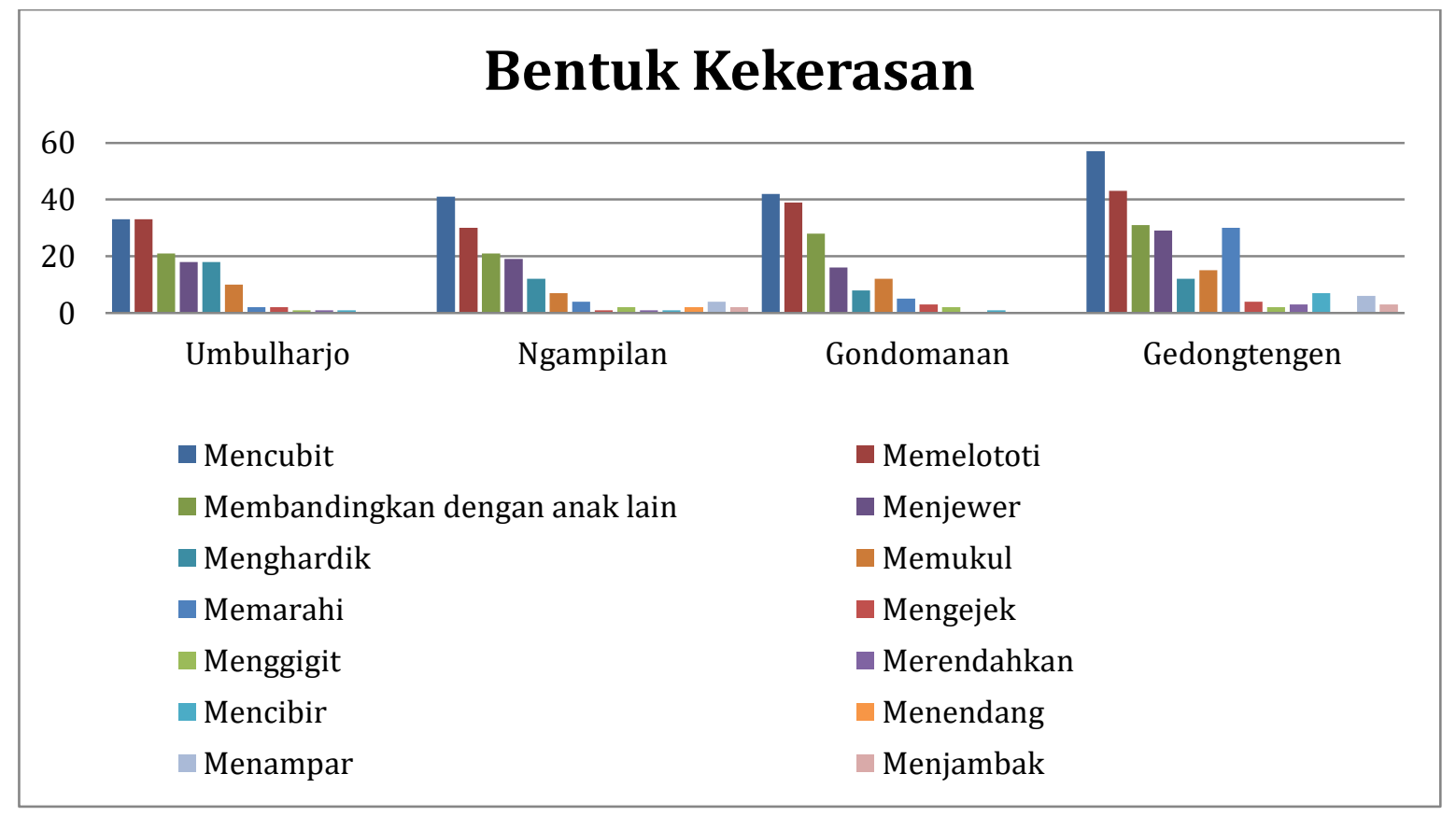

Grafik 1. Bentuk Kekerasan Orangtua terhadap Anak 
Tiga bentuk kekerasan dengan jumlah respon terbanyak adalah mencubit $(23 \%)$, memelototi (21\%), dan membandingkan dengan anak lain (15\%). Mencubit merupakan salah satu bentuk kekerasan fisik sementara memelototi dan membandingkan dengan anak lain termasuk dalam kekerasan non-fisik. Secara keseluruhan untuk kekerasan fisik terdapat $46 \%$ dan kekerasan non fisik terdapat $54 \%$.

Bentuk kekerasan fisik yang paling banyak dilakukan oleh orangtua berupa mencubit $(23 \%)$ dan menjewer $(21 \%)$. Sementara bentuk kekeraan fisik yang lebih berat seperti menendang didapati sebanyak 2 responden, menampar sebanyak 20 responden dan memukul sebanyak 44 responden. Yang menarik dari hasil temuan ini adalah kecamatan Gedongtengen memberikan respon paling banyak hampir di setiap bentuk kekerasan, misalnya pada respon menampar, sebanyak 16 dari 20 respon $(80 \%)$ berasal dari Kecamatan Gedongtengen.

Pada kekerasan verbal Kecamatan Gedongtengen juga memberikan respon terbanyak dibandingkan kecamatan lain. Misalnya kekerasan verbal dalam bentuk memarahi dengan kata-kata kasar dan kotor di kecamatan ini mendapat 30 dari 41 respon (73\%), dan dalam bentuk mencibir mendapat 7 dari 10 respon (70\%). Intensitas perlakuan keras terhadap anak paling banyak juga didapatkan dari kecamatan ini. Sebaliknya, untuk opsi tidak pernah melakukan kekerasan pada anak Kecamatan Gedongtengen mendapat respon paling sedikit yaitu 2 respon (8\%) sedangkan Kecamatan Umbulharjo sebanyak 11 respon (42\%), Kecamatan Ngampilan sebanyak 6 respon (23\%) dan Kecamatan Gondomanan sebanyak 7 respon $(27 \%)$.

Dilihat dari peringkat bentuk kekerasan yang dilakukan orangtua di masing-masing kecamatan diketahui bahwa orangtua paling banyak mencubit dan memelototi. Jika diakumulasi berdasarkan bentuk kekerasannya, orangtua lebih banyak melakukan kekerasan terhadap anak dalam bentuk non fisik (54\%). Pada aitem yang mengungkap hal ini responden diperbolehkan memilih lebih dari satu opsi sehingga tidak menutup kemungkinan bahwa terdapat orangtua yang pernah melakukan kekerasan secara fisik maupun non-fisik. Kekerasan fisik seperti ini secara langsung berdampak pada fisik dan psikologis anak. Anak akan menunjukkan respon tertentu terhadap kekerasan orangtuanya baik secara overt maupun covert. Pada penelitian ini respon terbanyak yang ditunjukkan anak adalah menangis dan diam. Lebih dari itu, kekerasan fisik memberikan dampak jangka panjang pada kesehatan anak, kesehatan mental, rentan terhadap penyalahgunaan obatobatan terlarang dan perilaku kriminal ketika anak bertambah usia (Nelson \& Caplan, 2014).

Lingkungan disebutkan sebagai salah satu faktor adanya kekerasan (Fitriana et al., 2015). Individu yang tinggal di lingkungan dimana banyak terjadi kekerasan maka individu tersebut rentan melakukan atau mengalami kekerasan itu sendiri. Data penelitian ini menunjukkan bahwa angka kekerasan pada anak dari empat Kecamatan didominasi oleh Kecamatan Gedongtengen. Hal ini dapat dikaji lebih dalam dengan melihat lingkungan dan kondisi di Kecamatan tersebut. Kecamatan ini memiliki dua kelurahan yaitu Kelurahan Sosromenduran dan Kelurahan Pringgokusuman. Dalam dua kelurahan ini terdapat beberapa tempat strategis seperti Stasiun Tugu dan Malioboro. Di sekitar tempat strategi ini terdapat beberapa lokalisasi seperti Pasar Kembang dan Bong Suwung. Di sekitar Bong Suwung tersebut tinggal preman-preman dan gali-gali yang identik dengan kekerasan. Hal ini disebabkan karena tempat ini merupakan lokalisasi prostitusi kelas menengah ke bawah sehingga konsumen atau pemakai merupakan buruh dan kuli (Pratama, 2016).

Kelurahan Pringgokusuman, Kecamata Gedongtengen merupakan tempat strategis yang mudah diakses sehingga mempunyai sisi positif dan negatifnya. Sisi positifnya tempat ini dekat dengan pusat pemerintahan kota dan fasilitas umum. Sementara sisi negatifnya tempat ini telah terpengaruh dengan budaya yang tidak sesuai dengan budaya Indonesia seperti seks bebas, hedonisme, minum-minuman keras dan penggunaan obat-obatan terlarang (Setyaningrum \& Nasiwan, 2017). Anak-anak yang tinggal dengan orangtua yang 
mengonsumsi obat-obatan terlarang dan minuman keras mempunyai risiko tinggi terhadap kesehatan yang buruk dan perilaku bermasalah (Osborne \& Berger, 2009).

Dampak kekerasan pada anak sangat beragam tergantung pada tingkat kekerasan itu sendiri. Pada penelitian ini ditemukan bahwa dampak ketika anak menerima perlakukan keras adalah menangis (28\%). Kondisi menangis ini merupakan salah satu ekspresi dari ketidaknyaman psikologis. Pada kasus kekerasan dengan tingkat yang lebih tinggi dampak fisik maupun psikologis anak bisa lebih fatal. Penelitian kualitatif terhadap seorang anak berusia 6 tahun yang mengalami kekerasan di lingkungan keluarganya dimana anak juga menyaksikan adiknya disiksa dengan dipukul, diinjak dan dibentur-benturkan ke dinding oleh kakeknya agar mengundang simpati orang lain (Anggadewi, 2007). Dampak psikologis yang dialami oleh anak tersebut antara lain perilaku agresif yang sulit terkendali, takut dengan ruang tertutup, toilet training yang buruk, perasaan tertekan dan selalu curiga dengan orang lain ditandai dengan senang membawa senjata tajam. Dampak lain yang ditunjukkan anak akibat kekerasan yang dilakukan orangtua dapat dilihat dalam grafik 2 berikut ini.

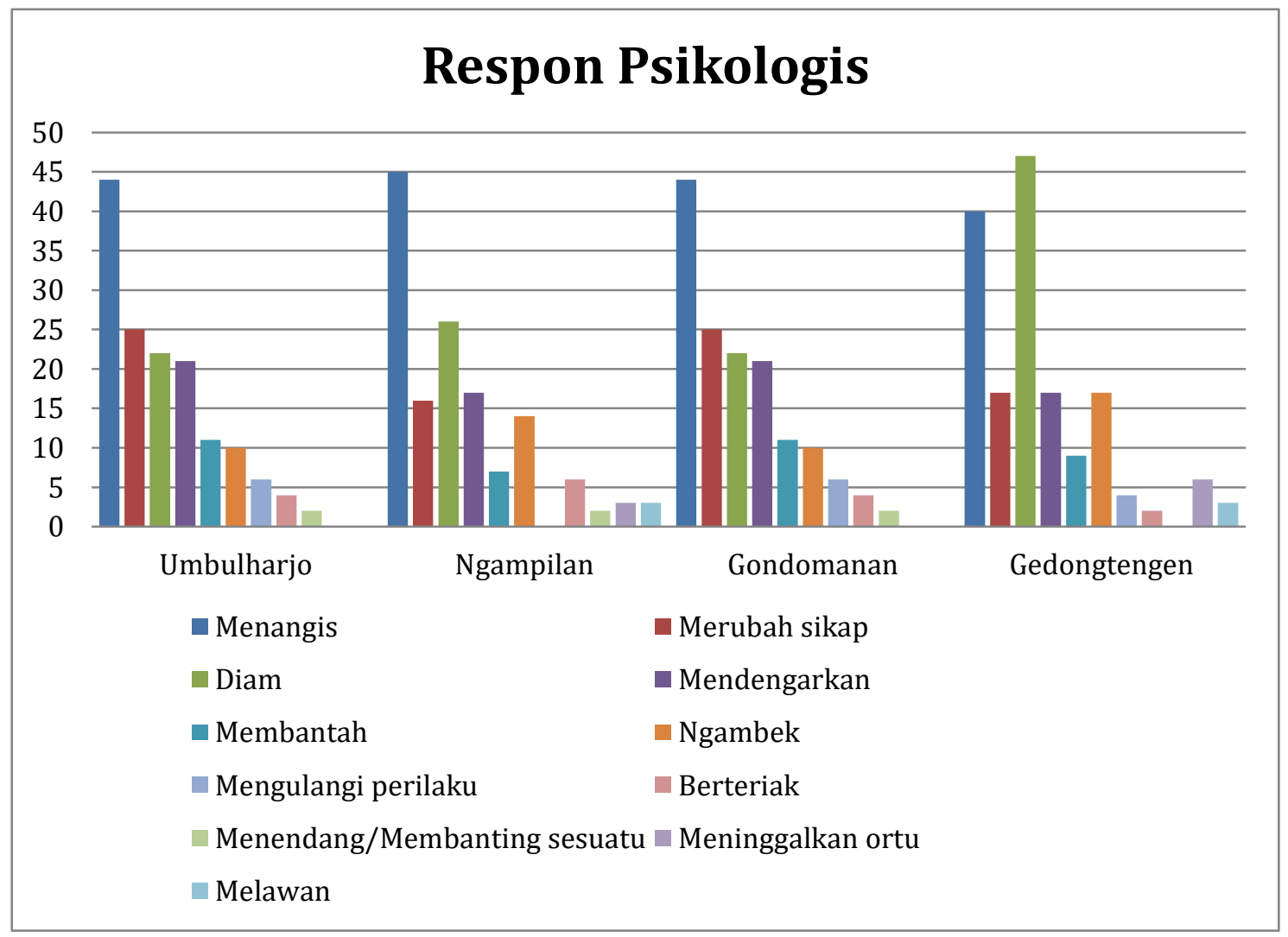

Grafik 2. Dampak Psikologis Anak akibat Kekerasan

Data dalam penelitan ini juga mengungkapkan alasan orangtua melakukan kekerasan kepada anak. Ke empat kecamatan menunjukkan modus yang sama dilihat dari alasan maupun peringkat alasan itu sendiri. Tiga alasan utama yang menyebabkan orangtua melakukan kekerasan yaitu ingin mendisiplinkan anak, orangtua menilai anak bandel atau nakal, dan ingin menghukum anak atas perilakunya. Dilihat dari grafik 3 di bawah ini, daerah yang memberi respon paling banyak untuk alasan ingin mendisiplinkan anak adalah Kecamatan Gondomanan (53 respon). Kemudian orangtua beranggapan bahwa anak nakal atau bandel paling tinggi direspon oleh Kecamatan Gedongtengen (49 respon). Sedangkan alasan ingin mendisiplinkan anak paling banyak direspon oleh Kecamatan Umbulharjo (17 respon). 


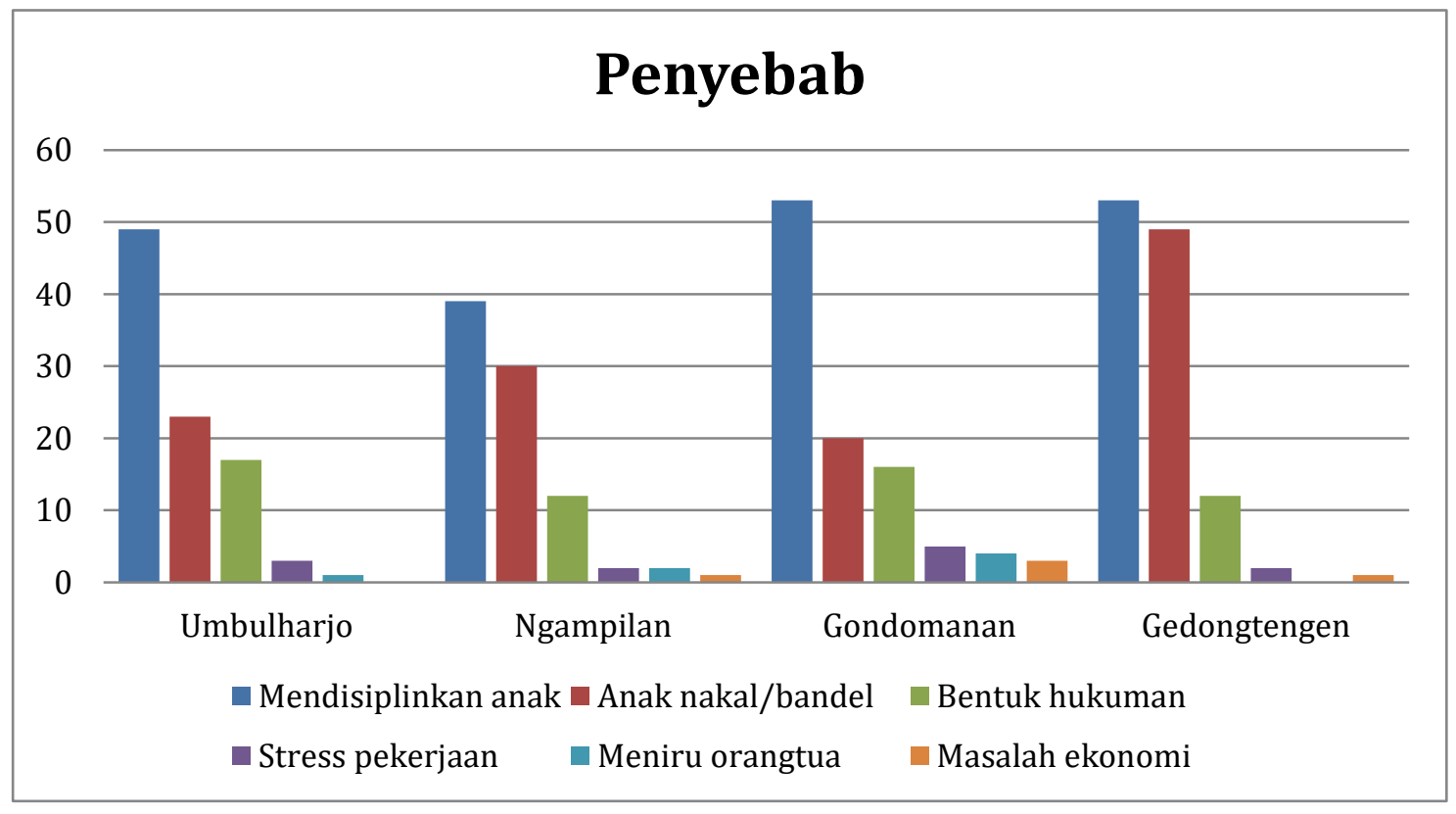

\section{Grafik 3. Penyebab Kekerasan Pada Anak}

Kekerasan dalam bentuk fisik maupun non fisik (verbal) terhadap anak menurut beberapa penelitian akan berdampak pada perkembangan anak itu sendiri. Ibu yang menggunakan kekerasan verbal dalam pengasuhan dapat berimplikasi pada masalah perilaku dan emosi anak. Secara psikologis, anak yang tumbuh dengan kekerasan verbal cenderung mengalami kesulitan dalam penyesuaian diri, menyalahkan diri sendiri dan emosi labil (Moore \& Pepler, 2013). Perkataan atau opini negatif akan terinalisasi oleh anak sehingga anak menganggap bahwa pendapat tersebut adalah benar dan melihat dirinya sebagai sosok yang negatif. Hal ini dapat semakin merendahkan harga diri pada anak tersebut (Mackowics, 2013).

Cicchetti dan Toth mengatakan bahwa perlakuan keras orangtua terhadap anak tidak hanya disebabkan oleh satu faktor saja (Santrock, 2007). Faktor lain seperti budaya, keluarga maupun perkembangan juga berkontribusi terhadap perlakuan tersebut. Ketika orangtua melakukan kekerasan pada anak bukan berarti orangtua tidak mencintai anaknya. Hal ini berangkat dari pemahaman bahwa setiap orangtua pasti memiliki rasa cinta dan tidak bermaksud melukai anaknya. Orangtua melakukan kekerasan dengan bertujuan anak menjadi disiplin dan berperilaku baik (Fitriana et al., 2015). Sayangnya banyak orangtua yang merasa frustrasi dengan perilaku anak sehingga melakukan kekerasan menjadi pilihan untuk dilakukan.

Pengasuhan yang menggunakan model hukuman baik secara fisik maupun non fisik bukan merupakan cara yang efektif dalam mengontrol perilaku anak dan memiliki efek samping yang buruk (Baumrind, 1966). Berkaitan dengan hal tersebut pola asuh menjadi salah satu unsur penting dalam perkembangan anak karena berkaitan dengan internalisasi dan eksternalisasi perilaku pada anak (Richters, 2010). Respon terbanyak dari alasan orangtua melakukan kekerasan adalah untuk mendisplinkan anak. Orangtua merasa frustrasi pada sikap anaknya sehingga melakukan kekerasan, data penelitian juga menunjukkan bahwa alasan kedua orangtua melakukan kekerasan adalah karena anak nakal atau bandel. Dari sini orangtua berpandangan bahwa melakukan kekerasan pada anak adalah salah satu bentuk hukuman bagi kenakalan tersebut. Pandangan ini menjadi alasan ketiga bagi orangtua melakukan kekerasan pada anak.

Kemampuan untuk meregulasi emosi merupakan salah satu faktor yang menjadi penyebab orangtua melakukan kekerasan berdasarkan penelitian ini. Hal ini ditunjukkan dengan pemahaman orangtua bahwa kekerasan tidak boleh dilakukan dengan alasan 
apapun namun pada praktiknya kekerasan tersebut tetap dilakukan pada anak. Selain itu faktor lingkungan juga dapat menjadi pemicu. Sebagaimana data yang telah ditunjukkan bahwa prevalensi kekerasan paling banyak terjadi di lingkungan yang sudah dikenal kawasan "keras" oleh masyarakat.

Penelitian ini menunjukkan bahwa bentuk kekerasan yang paling banyak dilakukan orangtua terhadap anak adalah mencubit, memelototi dan membandingkan dengan anak lain. Adapun penyebab perilaku tersebut diantaranya orangtua ingin mendisiplinkan anak, memiliki pandangan bahwa anak bandel, dan ingin memberikan hukuman pada anak. Dampak dari kekerasan yang dilakukan orangtua adalah anak menangis atau diam saja.

\section{SIMPULAN}

Kekerasan pada anak merupakan masalah kompleks. Bentuk, penyebab, dan dampak kekerasan sangat bervariasi di setiap kasusnya. Melakukan identifikasi terhadap kekerasan merupakan salah satu langkah awal untuk memahami kondisi pengasuhan dan digunakan sebagai dasar untuk melakukan intervensi pencegahan kekerasan tersebut. Kekerasan bukan menjadi perlakuan yang tepat untuk diterapkan pada anak usia dini mengingat dampak yang akan dirasakan oleh anak akan terbawa hingga dewasa. Dengan memahami penyebabpenyebab kekerasan, semestinya perilaku tersebut dapat dicegah untuk menjaga pengasuhan yang berkualitas serta membentuk anak-anak tumbuh yang bahagia.

\section{UCAPAN TERIMAKASIH}

Terimakasih peneliti ucapkan kepada pihak-pihak terkait dalam penelitian ini terutama orang tua yang memiliki anak usia 4-6 tahun yang bersekolah di Gondomanan, Umbulharjo, Gedongtengen, dan Ngampilan Yogyakarta.

\section{DAFTAR PUSTAKA}

Anggadewi, B. E. T. (2007). Studi Kasus tentang Dampak Psikologis Anak Korban Kekerasan dalam Keluarga.

Baumrind, D. (1966). Effects of authoritative parental control on child behavior. Child Development, 37(4), 887-907. https://doi.org/10.2307/1126611

Connolly, G. J. (2017). Applying social cognitive theory in coaching athletes: The power of positive role models. A Journal for Physical and Sport Educators, 30(3), 23-29. https:/ / doi.org/10.1080/08924562.2017.1297750

Fitriana, Y., Pratiwi, K., \& Sutanto, A. V. (2015). Faktor-faktor yang berhubungan dengan perilaku orangtua dalam melakukan kekerasan verbal terhadap anak usia prasekolah. Jurnal Psikologi Undip, 14(1), 81-93. https:// doi.org/10.14710/jpu.14.1.81-93

Lundahl, B. W., Nimer, J., \& Parsons, B. (2006). Preventing child abuse: A meta-analysis of parent training programs. Research on Social Work Practice, 16(3), 251-262. https:// doi.org/10.1177/1049731505284391

Mackowics, J. (2013). Verbal abuse in upbringing as the cause of low self-esteem in children. European Scientific Journal, 2, 474-478.

Moore, T. E., \& Pepler, D. J. (2013). Wounding words: Maternal verbal aggression and children's adjustment. Journal of Family Violence.

Nelson, G., \& Caplan, R. (2014). The prevention of child physical abuse and neglect: An update. Journal of Applied Research on Children: Informing Policy for Children at Risk, 5(1), Family Well-Being and Social Environments Article 3.

Nindya, P. N., \& Margaretha, R. (2012). Hubungan antara kekerasan emosional pada anak terhadap kecederungan kenakalan remaja. Jurnal Psikologi Klinis Dan Kesehatan Mental, 1(2), 1-9. 
DOI: 10.31004/obsesi.v4i2.451

Osborne, C., \& Berger, L. M. (2009). Parental substance abuse and child well-being: A consideration of parents's gender and coresidence. Journal of Family Issues, 30(3), 341368, 30(3), 341-368. https:// doi.org/10.1177/0192513X08326225.

Pratama, D. (2016). Penegakan hukum atas praktek prostitusi di Yogyakarta (Studi atas praktek prostitusi di rel kereta api ngebong Kecamatan Gedongtengen.

Puspitasari, I., \& Wati, D. E. (2018). Strategi parent-school partnership: Upaya preventif separation anxiety disorder pada anak usia dini. Yaa Bunayya: Jurnal Pendidikan Anak Usia Dini, 2(1), 49-60. https:// doi.org/10.24853/yby.2.1.49-60

Putri, A. M., \& Santoso, A. (2012). Persepsi orang tua tentang kekerasan verbal pada anak. Jurnal Keperawatan Diponegoro, 1(1), 22-29.

Richters, K. S. (2010). Child Temperament, Parenting Styles, and Internalizing and Externalizing Behaviors As Part of A Comprehensive Assessment Tool. https:// pdfs.semanticscholar.org/3628/26dd06de75483a4b3a8d1a94797a62aba74d.p df

Santrock, J. W. (2007). Life-Span Development Perkembangan Masa Hidup Edisi Kelima Jilid I. Penerbit Erlangga.

Setyaningrum, I., \& Nasiwan, Dr. (2017). Pembentukan karakter anak melalui program jam belajar masyarakat RW 01 Jlagran Kelurahan Pringgokusuman Kecamatan Gedongtengen Yogyakarta. Universitas Negeri Yogyakarta.

Setyawan, D. (2015). KPAI: Pelaku Kekerasan Terhadap Anak Tiap Tahun Meningkat. Www.Kpai.Go.Id.

Sugiyono. (2008). Metode Penelitian Kuantitatif, Kualitatif, dan RED. Alfabeta.

Tamisa, A. (2016). Latar belakang kecemasan anak pra sekolah kasus A (IM) siswa taman kanak-kanak ArRahman Palembang. Psikis Jurnal Psikologi Islam, 2(2), 117-134.

Widiastuti, D., \& Sekartini, R. (2005). Deteksi dini, faktor risiko, dan dampak perlakuan salah pada anak. Sari Pediatri, 7(2), 105-112. https://doi.org/10.14238/sp7.2.2005.105-12. 